\title{
Facies Architecture of the Fluvial-Aeolian Buchan Formation (Upper Devonian) and Its Implications on Field Exploration: A Case Study from Ardmore Field, Central North Sea, UK
}

\author{
Longxun Tang*, Stuart Jones, Jon Gluyas \\ Department of Earth Sciences, Durham University, South Road, Durham, UK \\ Email: *longxun.tang@durham.ac.uk
}

How to cite this paper: Tang, L.X., Jones, S. and Gluyas, J. (2017) Facies Architecture of the Fluvial-Aeolian Buchan Formation (Upper Devonian) and Its Implications on Field Exploration: A Case Study from Ardmore Field, Central North Sea, UK. International Journal of Geosciences, 8, 902924. https://doi.org/10.4236/ijg.2017.87052

Received: June 30, 2017

Accepted: July 25, 2017

Published: July 28, 2017

Copyright $\odot 2017$ by authors and Scientific Research Publishing Inc. This work is licensed under the Creative Commons Attribution International License (CC BY 4.0).

http://creativecommons.org/licenses/by/4.0/

\begin{abstract}
The Upper Devonian Buchan Formation in the Central North Sea is a typical terrestrial deposit and predominantly comprises fine to medium-grained sandstones with occasional conglomerates and mudstones. The Buchan Formation has been previously described as being made up mostly of braided fluvial sandstones; however, this study confirms the presence and significance of aeolian sandstones within this fluvial-dominated sequence. Facies architecture is investigated through analogue outcrop study, well log curves and numerical facies modelling, and the results show contrasting differences between fluvial and aeolian facies. The fluvial facies is composed of multiple superimposed and sand-dominated fining-upward cycles in the vertical direction, and laterally an individual cycle has a large width/thickness ratio but is smaller than the field scale. However, the high channel deposition proportion (CDP, average value $=72 \%$ ) in fluvial-dominated intervals means that it is likely all the sand bodies are interconnected. Aeolian facies comprise superimposed dune and interdune depositions and can be laterally correlated over considerable distances (over $1 \mathrm{~km}$ ). Although the aeolian sandstones are volumetrically minor (approx. 30\%) within the whole Buchan Formation, they have very high porosity and permeability $(14.1 \%-28 \%, 27-5290 \mathrm{mD})$ and therefore are excellent potential reservoirs. The fluvial sandstones are significantly cemented by quartz overgrowth and dolomite and by comparison with the aeolian sandstones are poor reservoirs. Aeolian sandstones can be differentiated from fluvial sandstones using several features: pin-stripe lamentation, good sorting, high visible porosity, friable nature and lack of muddy or conglomeratic contents; these characteristics allow aeolian sandstones can be tentatively recognized by low gamma ray values, high sonic transit time and low density
\end{abstract}


in uncored wells. The thin, laterally correlatable and permeable aeolian sandstones within the Buchan Formation are effective reservoirs and could form important exploration targets when the Devonian is targeted elsewhere in the North Sea.

\section{Keywords}

Central North Sea, Upper Devonian, Fluvial-Braided, Aeolian, Facies Architecture, Aeolian Facies Recognition

\section{Introduction}

The hydrocarbon reservoirs in the Ardmore Field (previous name "Argyll", now part of "Alma/Galia project") comprise Upper Devonian Buchan Formation, Permian Rotliegend sandstone and Permian Zechstein carbonates [1] [2] [3]. The Permian Rotliegend and Zechstein groups are important reservoirs in the North Sea and have been researched by numerous studies [4]-[9]. For the Devonian strata, the reservoir properties of Buchan Formation are highly variable, the depositional facies were poorly understood and just briefly described as fluvial deposition under a semi-arid to arid setting [2] [10], there were no reports focused on detailed facies analysis, how the facies architecture of Buchan Formation displays in the subsurface and the relationship between different facies and highly variable reservoir properties.

In this study, we have re-examined the cores and hence re-interpreted depositional facies of Buchan Formation in the Ardmore field. The results show that the Buchan Formation is composed by mixed fluvial-aeolian sandstones, and the aeolian sandstone intervals have the best reservoir quality among the Buchan formation. The facies architecture and porosity/permeability relationships of fluvial and aeolian intervals show distinct differences which are responsible for the highly variable reservoir properties. Therefore, the main aims of this paper are: (1) to characterize and interpret the main facies associations; (2) to simulate the facies architecture based on analogue outcrop study and the well log data; (3) to propose a new facies model for the fluvial-aeolian depositions of the Buchan Formation; and (4) to set several tentative criteria for recognizing aeolian sandstones in uncored wells. This is the first-time study on the fluvial-aeolian facies architecture of the offshore Devonian reservoirs in the UK North Sea. The results provide insights into facies architecture of Buchan sandstones, improve the knowledge of poorly understood Devonian in the North Sea and are useful for forecasting the quality of Upper Devonian sandstone reservoirs in the Central North Sea and other areas ahead of drilling.

During this study, lithofacies description and facies identification were carried out on cores from six wells in the Ardmore field; the study on the analogue outcrops provided useful information of the geometry and lateral extent of the fluvial facies associations; the facies architecture in the subsurface was achieved by 
the facies modelling module of the Schlumberger Petrel software based on the integration of outcrops study, core data and well logging interpretation.

\section{Geological Background}

\subsection{Tectonic Setting of the Ardmore Field}

The Ardmore Field is located on the Argyll Ridge, a large SW-NE trending Palaeozoic age tilted fault block on the south-western flank of the Central Graben in Block 30/24, UK North Sea, about $350 \mathrm{~km}$ south-east from Aberdeen. The field is a horst feature with the crest in the north and fault closure to the northeast. It measures $2.5 \mathrm{~km}$ wide and $6 \mathrm{~km}$ long (Figure 1(A)). A combination of dip and faulting defines the limits of the field on the north-west and south-east flanks, while dip closure defines the southern limits of the field. The major fault trends are in two main directions, WNW-ESE cut by NW-SE faults (Figure 1(B)). Top seal of the field is provided by Triassic shale to the far west, Jurassic shale in the mid-part of the field and impermeable Chalk at the north-eastern crest [10]. The trap relies heavily on the major NW-SE trending graben edge faults to the northeast and southwest of the field while dip closure occurs to the northwest and west.
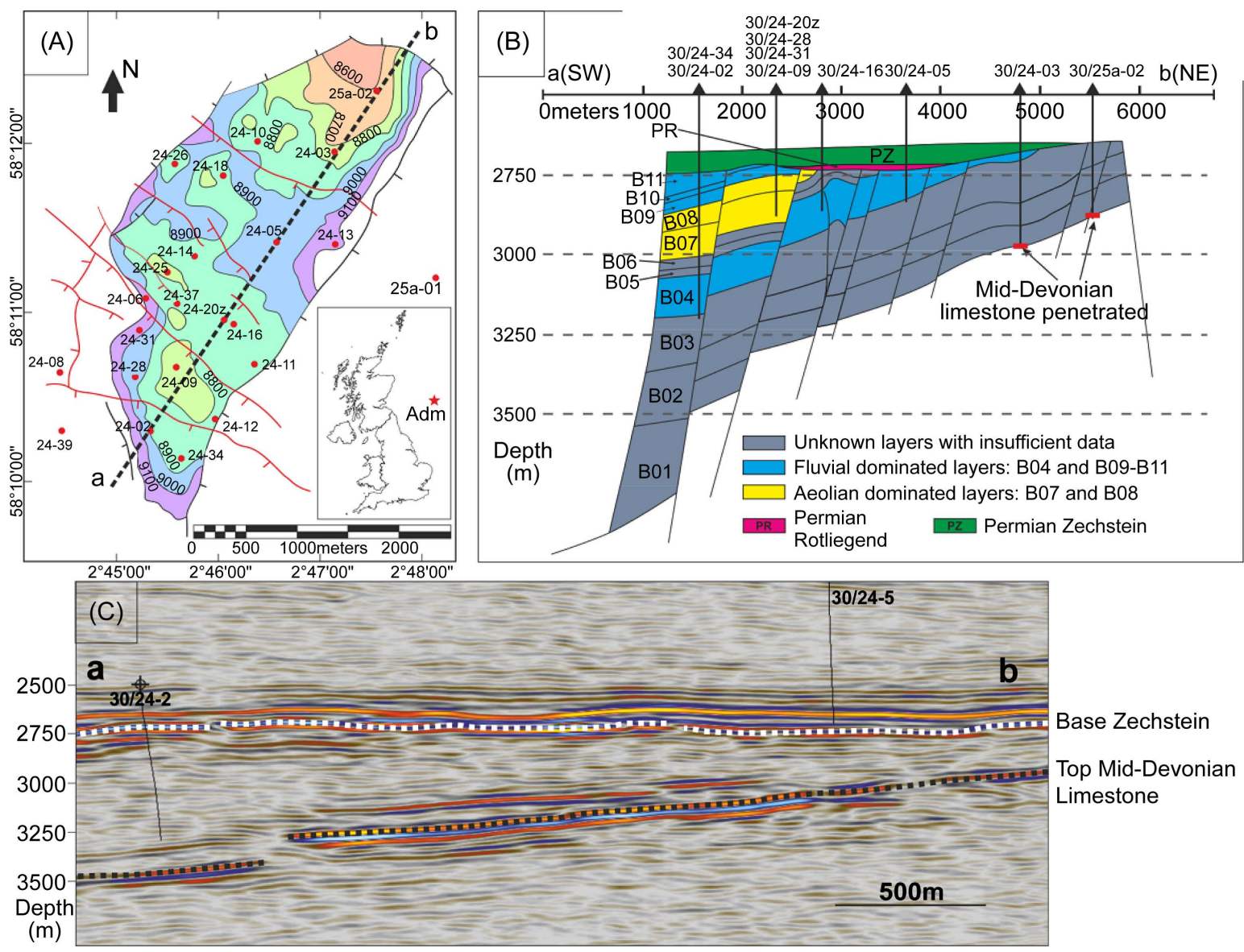

Figure 1. (A) Location and main structure elements of Ardmore field (Adm). (B) Cross section for a-b profile, slightly modified from Gluyas, Mair [10]. (C) Seismic section for a-b profile. 


\subsection{Stratigraphy of the Buchan Formation}

The Devonian sequence in the Ardmore Field comprises a succession of the Middle Devonian Kyle limestone and Upper Devonian Buchan sandstone. The succession dips to the south-west, and is separated from the Permian by a palaeo-topographic unconformity, in which successively younger stratigraphic units in the Devonian sub crop towards the south-west. Although the pre-Permian surface has topography it also dips to the SW, this has the effect of making the oldest part of the Buchan sandstone subcrop the unconformity in the NE of the field and thus the youngest Devonian in the SW slightly deeper (Figure 1(B)).

The Middle Devonian Kyle Group is a fairly thin unit (c. 105 m. thick, Figure 1(C)) comprising limestones and minor evaporates [11]. In the adjacent Auk Field, this succession rest unconformably on pre-Devonian basement [12]; this might be similar in Ardmore as inferred from seismic interpretation. The Middle Devonian limestone is mainly encountered in Ardmore wells 30/24-03 and 30/25a-02 (Figure 1(B)), and forms a strong intra-Devonian seismic reflector throughout the area of the field (Figure $1(C)$ ).

The Upper Devonian Buchan Formation comprises a thick, generally upwardcoarsening succession of shales of mixed shallow marine and sabkha environment at the base, passing upwards into mainly fluvial and aeolian sandy sediments (Figure 2). The whole Buchan succession lacks clear seismic stratigraphic markers, a combination of log and core data has been used to divide the stratigraphic units for the Upper Devonian group: B01 is the oldest unit overlying the Middle Devonian Limestone, and B11 is the youngest unit [10]. In the absence of bio-stratigraphic data, sedimentary structures and lithofacies associations have been applied to help correlation [10]. The total thickness of the Buchan Formation is nowhere documented due to the combination of erosion below the Devonian-Permian unconformity, lateral thickness variation and incomplete well penetrations. The estimated thickness is about $500-800 \mathrm{~m}$ according to the seismic profile (Figure 1(C)).

\section{Facies Analysis}

The detailed lithofacies study forms the basis of this paper, six wells were chosen because they comprises important fluvial and aeolian intervals in the Ardmore field, and have a good data availability (drilled cores with good recovery and well log data).

The lithofacies in the Ardmore field can be roughly divided into three associations according to the dominant grain size grades: conglomerates $(G)$, sandstones ( $\mathrm{S}$ ) and fine-grain sediments (F). The further detailed lithofacies identification has confirmed eight sub-types (Table 1), the classification of lithofacies is mainly based on the original scheme of Miall [13].

\subsection{Fluvial Facies Association}

The fluvial facies is volumetrically major (approx. 70\%) in the whole Buchan 
L. X. Tang et al.

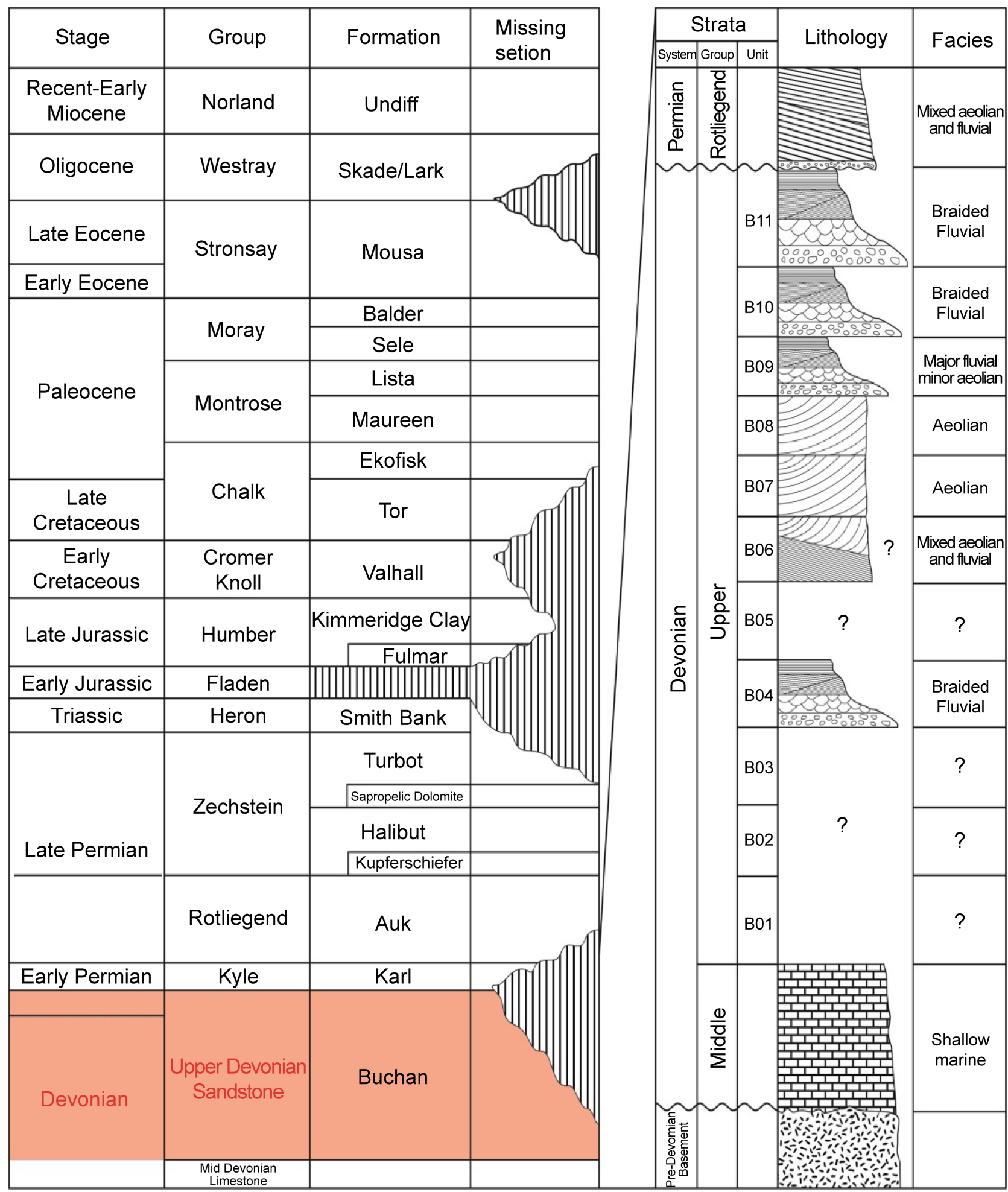

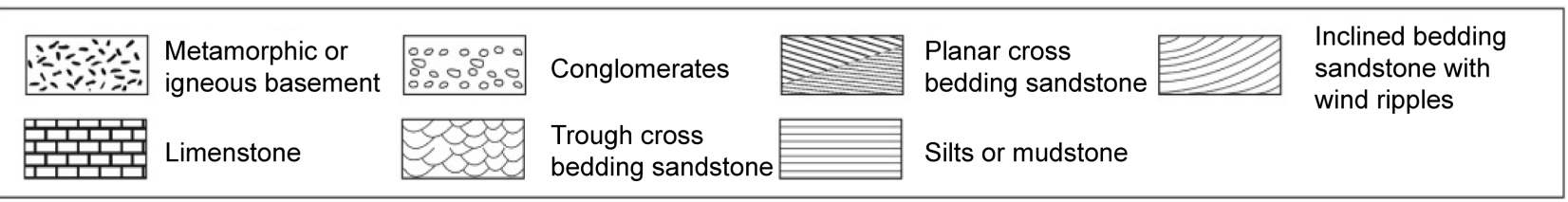

Figure 2. Stratigraphy column and sedimentary logs of the Ardmore field. 
Table 1. The lithofacies types in the Ardmore field and the corresponding descriptions, sedimentary structures, interpretations and appearances.

\begin{tabular}{|c|c|c|c|c|c|}
\hline Facies & Lithofacies code & Lithology description & Structures & Interpretation & Appearances \\
\hline \multirow{6}{*}{ Fluvial } & $\mathrm{Gm}$ & $\begin{array}{l}0.5 \text { - } 1 \mathrm{~m} \text { thick, sandy matrix-supported, } \\
\text { red brown intra-formational mudstone } \\
\text { or grey to white-grey quartz pebbles } \\
\text { conglomerates, pebbles are around } 1 \text { - } 3 \\
\mathrm{~cm} \text { in diameter. }\end{array}$ & $\begin{array}{l}\text { Massive to } \\
\text { crudely bedding }\end{array}$ & Basal lag deposits & $\begin{array}{l}\text { B04, B09, } \\
\text { B10, B11 }\end{array}$ \\
\hline & St & $\begin{array}{l}0.5-1.5 \mathrm{~m} \text { thick, fine to medium-grained } \\
\text { sandstones, containing grouped or solitary } \\
\text { sets of trough cross laminations }\end{array}$ & $\begin{array}{l}\text { Trough } \\
\text { cross-bedding }\end{array}$ & $\begin{array}{l}\text { Downstream migration } \\
\text { of sinuous-crested dunes } \\
\text { in fluvial channels (lower } \\
\text { flow regime) }\end{array}$ & $\begin{array}{l}\text { B04, B09, } \\
\text { B10, B11 }\end{array}$ \\
\hline & $\mathrm{Sp}$ & $\begin{array}{l}0.5 \text { - } 1 \mathrm{~m} \text { thick, fine to medium-grained } \\
\text { sandstone with solitary sets of planar cross } \\
\text { laminations, better sorted and cleaner than } \\
\text { St and lack mudstone or quartz pebbles }\end{array}$ & $\begin{array}{l}\text { Planar } \\
\text { cross-bedding }\end{array}$ & $\begin{array}{l}\text { Transverse and linguoid } \\
\text { sand bars in fluvial channels } \\
\text { (lower flow regime) }\end{array}$ & $\begin{array}{l}\text { B04, B09, } \\
\text { B10, B11 }\end{array}$ \\
\hline & Sh & $\begin{array}{l}0.2 \text { - } 0.5 \mathrm{~m} \text { thick, red-brown, fine-grained } \\
\text { sandstones with millimetre-scaled thin } \\
\text { laminations. }\end{array}$ & $\begin{array}{l}\text { Horizontal } \\
\text { lamination }\end{array}$ & $\begin{array}{l}\text { Flash floods deposits } \\
\text { (lower flow regime) }\end{array}$ & $\begin{array}{l}\text { B04, B09, } \\
\text { B10, B11 }\end{array}$ \\
\hline & $\mathrm{Fl}$ & $\begin{array}{l}0.2-1 \mathrm{~m} \text { thick, argillaceous and micaceous, } \\
\text { very fine-grained sandstones to siltstones. }\end{array}$ & $\begin{array}{l}\text { Thin laminations } \\
\text { with soft sediment } \\
\text { deformation }\end{array}$ & $\begin{array}{l}\text { Temporary floodplains } \\
\text { and inactive or abandon } \\
\text { channels }\end{array}$ & $\begin{array}{l}\text { B04, B09, } \\
\text { B10, B11 }\end{array}$ \\
\hline & $\mathrm{Fm}$ & $\begin{array}{l}0.2-0.5 \mathrm{~m} \text { thick, micaceous dark red-brown } \\
\text { silty mudstones and mudstones }\end{array}$ & Massive bedding & Overbank & $\begin{array}{l}\text { B04, B09, } \\
\text { B10, B11 }\end{array}$ \\
\hline \multirow{2}{*}{ Aeolian } & Sps & $\begin{array}{l}0.5 \text { - } 1 \mathrm{~m} \text { thick, upper fine- to medium-grained, } \\
\text { well sorted, well rounded sandstones. High } \\
\text { visible porosity, friable nature and the } \\
\text { absence of muddy or conglomeratic } \\
\text { intra-clasts. }\end{array}$ & $\begin{array}{l}\text { Pin-stripe } \\
\text { lamination }\end{array}$ & Dune & B07, B08 \\
\hline & Sw & $\begin{array}{l}1 \text { - } 2 \text { m thick, very fine- to medium-grained } \\
\text { sandstones, moderately to well sorted, } \\
\text { locally developed mud desiccation, } \\
\text { de-water structure, cross-bedding ripples } \\
\text { and argillaceous streaks }\end{array}$ & $\begin{array}{l}\text { Discontinuous } \\
\text { wavy lamination } \\
\text { with several local } \\
\text { structures }\end{array}$ & $\begin{array}{l}\text { Interdune with fluctuating } \\
\text { dry and wet conditions }\end{array}$ & B07, B08 \\
\hline
\end{tabular}

Formation of the Ardmore Field and composed by multiple fining-upward cycles (see details in facies architecture part). In this study, two types of fluvial deposit are identified: fluvial channel facies and flood plain facies.

\subsubsection{Fluvial Channel Facies}

\section{a) Conglomerate $(\mathrm{Gm})$}

Description: this lithofacies occurs in a minor proportion $(<10 \%)$. It is commonly developed as thin lags $(0.5-1 \mathrm{~m})$ on erosional planes. The conglomerates are generally composed of red brown intra-formational mudstone clasts (Figure $3(\mathrm{~A})$ ) or grey to white-grey quartz pebbles (Figure $3(\mathrm{~B})$ ) up to $3 \mathrm{~cm}$ in diameter with a fine to medium grained sandy matrix. The muddy clasts and quartz pebbles are sub-angular to sub-round (Figure 3(A), Figure 3(B)), and the platy ones are often aligned or display crude imbrication (Figure 3(B)). This lithofacies generally occurs at base of the fining-upward cycle. 

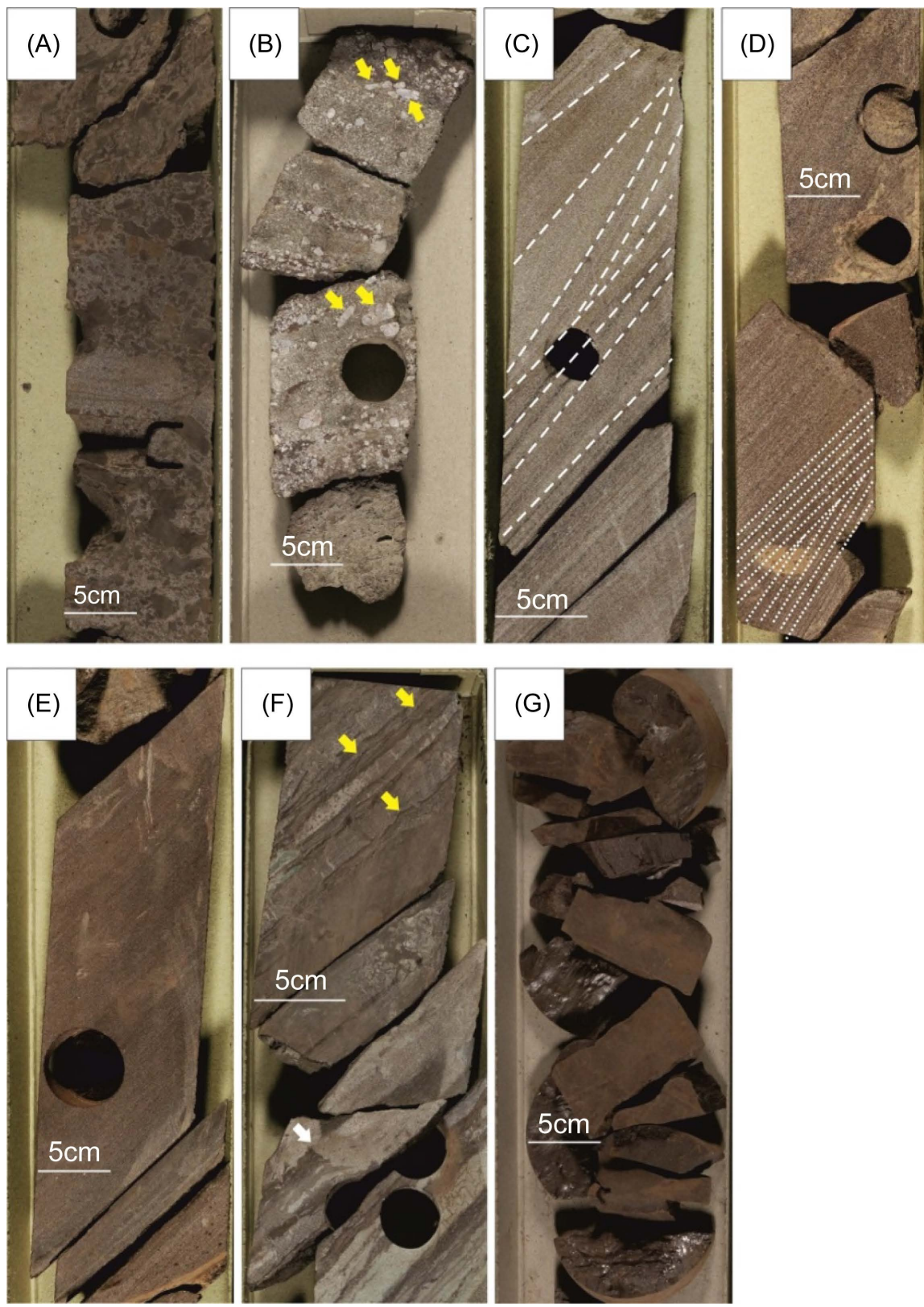

Figure 3. Core photos of fluvial-associated lithofacies. (A) Lithofacies Gm. Dark redbrown muddy cobbles with $0.5-2.5 \mathrm{~cm}$ grain size in a sandy supported matrix. Well 30/24-20z, 3159.1 m, Layer B04. (B) Lithofacies Gm. White and grey, sub-angular to subrounded quartz pebbles with $1-2 \mathrm{~cm}$ grain size in a sandy supported matrix, the platy ones are aligned or display crude imbrication (yellow arrows). Well 30/24-34, $2972.1 \mathrm{~m}$, Layer B11. (C) Lithofacies St. Trough cross- bedded, medium to fine sandstones, note the white dash lines indicate the trough sets. Well 30/24-20z, 3121.7 m, Layer B04. (D) Lithofacies Sp. Planar cross bedding, medium to fine sandstones; note the white dot line indicate the interface between two planar bedding sets, Well 30/24-20z, $3172.7 \mathrm{~m}$, Layer B04. (E) Lithofacies Sh. Red-brown fine-grained sandstones with millimetre-scale laminates. Well 30/24-20z, 3164 m, Layer B04. (F) Lithofacies Fl. Laminated very fine grain sandstones and silts with ripples or soft sediment deformation (yellow arrows) and the muddy desiccation cracks (white arrow). Well 30/24-20z, 3129.8 m, Layer B04. (G) Lithofacies Fm. Dark brown mudstones with no obvious beddings. Well 30/24-34, 2945.3 m, Layer B11. 
Interpretation: this lithofacies represents a depositional setting with very high energy, which can be explained as the fluvial basal lag deposition, the wide range of sediment grain size (from fine sand to conglomeratic grade) represents a clast-rich debris flow [13].

b) Sandstones (St, Sp and Sh)

Description: fine to medium-grained sandstone bodies up to $10 \mathrm{~m}$ thick comprise the main lithology type (approx. 80\%) of fluvial channel facies and various sedimentary structures have been recognized (Table 1). Typically the sandstone bodies are organized into three lithofacies: 1) Trough cross-bedding (St);2) planar cross bedding (Sp); and 3) inclined horizontal lamination (Sh).

Lithofacies St (Figure $3(\mathrm{C})$ ) is common within the whole fluvial interval (approx. 30\% - 40\%) and consists of $0.5-1.5 \mathrm{~m}$ thick, fine to medium-grained sandstones with grouped or solitary sets of trough cross laminations. The sets generally range in thickness from approximately $10-30 \mathrm{~cm}$. The sedimentary structures are defined by argillaceous laminae. This lithofacies forms an important unit within fining-upward cycle and commonly passes transitionally upwards into lithofacies Sp, Sh, Fl or Fm.

Lithofacies Sp (Figure 3(D)) is also common (approx. 20\% - 30\%) and consists of $0.5-1 \mathrm{~m}$ thick, fine to medium-grained sandstone with solitary sets of planar cross beddings. The sandstones are better sorted and cleaner than lithofacies St and lack mudstone or quartz pebbles. This lithofacies also forms an important unit within fining-upward cycle and commonly passes transitionally upwards into lithofacies Sh, Fl or Fm.

Lithofacies Sh (Figure 3(E)) is subordinate (10\% - 20\%) and consists of 0.2 $0.5 \mathrm{~m}$ thick, fine-grained sandstones with well-developed inclined horizontal laminations. The millimetre-scaled thin laminations are defined by dense concentrations of fine-grained detrital rock fragments in red-brown colour, and the coarser and cleaner laminates show lighter colour. This lithofacies occurs towards the upper part of fining upward cycles.

Interpretation: the fine- to medium-grained sandstones with various sedimentary structures record the different types of channel migration and accretion. The trough cross bedding represents the result of downstream migration of sinuous-crested dunes, which was usually formed by braided channel-fill deposits under a lower flow regime [14]. The planar cross bedding usually represents the transverse and linguoid sand bars in fluvial channels, and this could be either the result of lateral or downstream accretions [14]. The inclined horizontal laminations could be interpreted as the plane-bed flow and was probably formed by the flash floods deposits within a distal sheet-flood sand-bed river system.

\subsubsection{Flood Plain Facies (Fl and Fm)}

Description: the flood plain facies consists of very fine laminated sandstones to siltstones with soft sediment deformation ( $\mathrm{Fl})$ and massive silty mudstones and mudstones (Fm). The lithofacies Fl (Figure $3(\mathrm{~F})$ ) consists of $0.2-1 \mathrm{~m}$ thick, argillaceous and micaceous, very fine-grained sandstones to siltstones. The argil- 
laceous content occurs as inclined parallel laminae, small ripple cross laminae, and discontinuous steaks and mud curls. Soft sediment deformation structures are common; some occasional desiccation cracks with infilled sands are also recorded (Figure 3(F)). The lithofacies Fm (Figure 3(G)) consists of $0.2-0.5 \mathrm{~m}$ thick, micaceous dark red-brown silty mudstones and mudstones with massive beddings, and usually occurs at the top of fining-upward cycles.

Interpretation: these finer-grained sediments record flood plain deposition resulting from overbank flood event [15]. The lithofacies Fl might be the temporary floodplains and inactive or abandon channels. The desiccation cracks with infilled sands indicate the occasional exposed setting under arid climate. The mudstones (Fm) were accumulated in the lowest energy zones; represent a quite standing water condition following flooding events.

\subsection{Aeolian Facies Association}

The aeolian facies is volumetrically minor in the whole Buchan Formation of the Ardmore Field (approx. 30\%). In this study, two types of aeolian deposit are identified: the pin-stripe laminated dune and discontinuous wavy laminated interdune sandstones.

\subsubsection{Lithofacies Sps: Pin-Stripe Laminated Sandstones (Figure 4(A))}

Description: this lithofacies form minor component (approx. 20\%) of aeolian facies and are characterized by $0.5-1 \mathrm{~m}$ thick, upper fine- to medium-grained, well sorted sandstones. The grains are well rounded and the thin pin-stripe laminates are commonly exhibited. The sandstones display large-scale crossbedding organized into 0.5 to $1 \mathrm{~m}$-thick sets, and the dip angle is about $35^{\circ}$. Additionally, there are several secondary features possessed by these deposits contrast them with the fluvial facies: high visible porosity, friable nature and the absence of muddy or conglomeratic intra-clasts.

Interpretation: the presence of well-rounded and sorted, upper fine- to mediumgrained, muddy or conglomeratic clast-free sandstones with pin-stripe laminates are typical features of the aeolian dune deposits [16] [17] [18]. The high-angle, relatively stable graded laminates are interpreted as sand-flow deposits, formed by avalanching of non-cohesive sands on dune slip faces [16]. The highly friable nature suggests the low cementation, which is responsible for high visible porosity.

\subsubsection{Lithofacies Sw: Discontinuous Wavy Laminated Sandstones}

Description: this lithofacies is the predominant type (approx. 80\%) in aeolian association and occurs interbedded with the dune sandstones; it is dominantly composed of $1-2 \mathrm{~m}$ thick, very fine- to medium-grained sandstones that are moderately to well sorted, with low-angle discontinuous wavy laminates. Several local sedimentary structures can be sighted, including the mud desiccation infilled by sands (Figure 4(B)), de-water structure (Figure 4(C)), cross-bedding ripples (Figure 4(D)) and argillaceous streaks (Figure 4(E)). Vertically, there is no obvious boundary between Sps and Sw. 

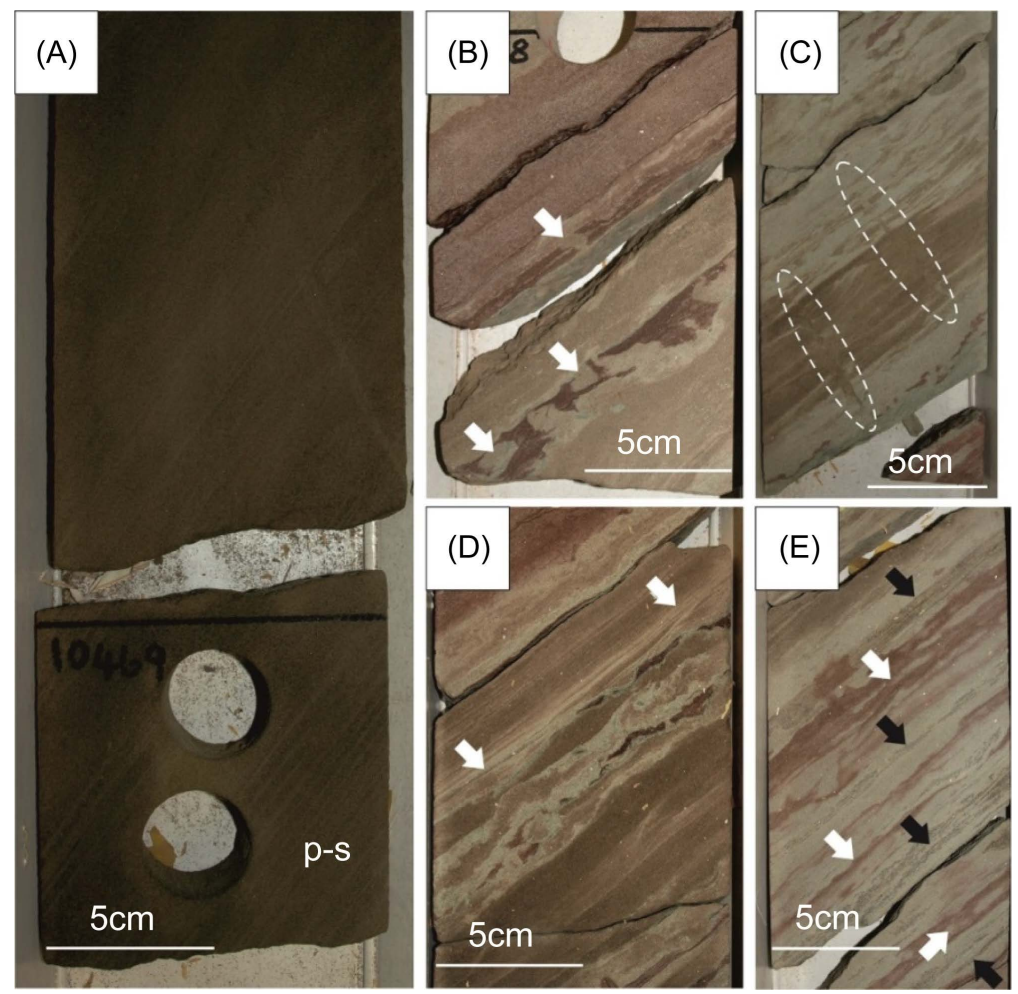

Figure 4. Core photos of aeolian-associated lithofacies. (A) The oil-stained, mediumgrained, pin-stripe (p-s) aeolian dune sandstones, Well 30/24-31, 3191 m, Layer B08. (B) Muddy-rich fine-grained interdune sandstones with muddy desiccation cracks (white arrows), Well 30/24-31, $3184.7 \mathrm{~m}$, Layer B08. (C) The de-watering (white dashed ellipse) sighted in a sandy-dominated interdune deposit, Well 30/24-31, 3187.8 m, Layer B08. (D) Centimetre-scale cross-bedding ripples (white arrows) sighted in a sandy- dominated interdune deposit, note the underlying soft sediment deformation. Well 30/24-31, 3183.8 m, Layer B08. (E) The discontinuous wavy laminations (white arrows) and argillaceous streaks (black arrows) sighted in a sandy-dominated interdune deposit. Well 30/24-31, 3189.3 m, Layer B08.

Interpretation: the discontinuous wavy laminates with several local sedimentary features suggest that this lithofacies represents the interdune environment. The interdune is usually located in low-relief areas of a dune system [19]; therefore, in the given fluvial-presented setting, the interdune area would be affected by fluvial depositions. The mud desiccation infilled by sands and de-water structures indicate dry condition, while the cross-bedding ripples and argillaceous streaks can represent a wetter condition [17]. The variation between dry and wet conditions could be associated with the fluctuations of the fluvial system.

\subsection{The Analogue Outcrop in Dunnet Head, Scotland}

This NW-SE trend outcrop profile is located in the Dwarwick Pier $\left(58^{\circ} 37^{\prime} \mathrm{N}\right.$ $03^{\circ} 22^{\prime} \mathrm{W}$, see Figure $1(\mathrm{~A})$. for location) and displays typical fluvial sandstones of the Upper Devonian formation. Due to the North Sea Basin was under similar tectonic, depositional and climate settings in the late Devonian age [20] [21], therefore, this outcrop is chosen as the analogue example for the geometry of 
fluvial sand bodies.

The medium to course-grained sandstones with red-buff and brown-buff coloured are predominant; the main lithofacies are sandstones with trough and planar cross beddings (Figure 5(B), Figure 5(C)), which commonly has soft sediment deformation (Figure $5(C)$ ); the conglomerates and fine grain sediments are rarely sighted.

The depositional environment was fluvial braided channels, probably on a low angle alluvial fan [22]. The possible sediment source area was the Scottish Northwest Highland [20], and the general transport direction was from SW to NE [22] [23]. The absence of fine-grained sediments, such as rip-up muddy clasts, might indicate that this locality was proximal to the sediment source area; and the rapid channel migration in lateral direction and consequent sediment reworking prevented the preservation of muddy sediments.

The outcrops provide a good opportunity to measure the geometry of the channel sand bodies. On the selected profile, nine fluvial channel units have been identified and named as $\mathrm{fc} 1$ to $\mathrm{fc} 9$ upwards (Figure 5(A)). The fluvial channel unit generally shows a sheet-like sand body, the thickness of an individual unit is from $0.45 \mathrm{~m}$ and up to $0.75 \mathrm{~m}$, and each unit is composed by thin laminates around $5-8 \mathrm{~cm}$. A single fluvial sand body is sometimes truncated by adjacent fluvial sand bodies (Figure 5(A)). The lateral extension of a single fluvial sand body can be tracked somewhere tens to nearly one hundred meters away from the selected profile, thus the width-thickness ratio is approximately 80:1 to 120:1 (Table 2).
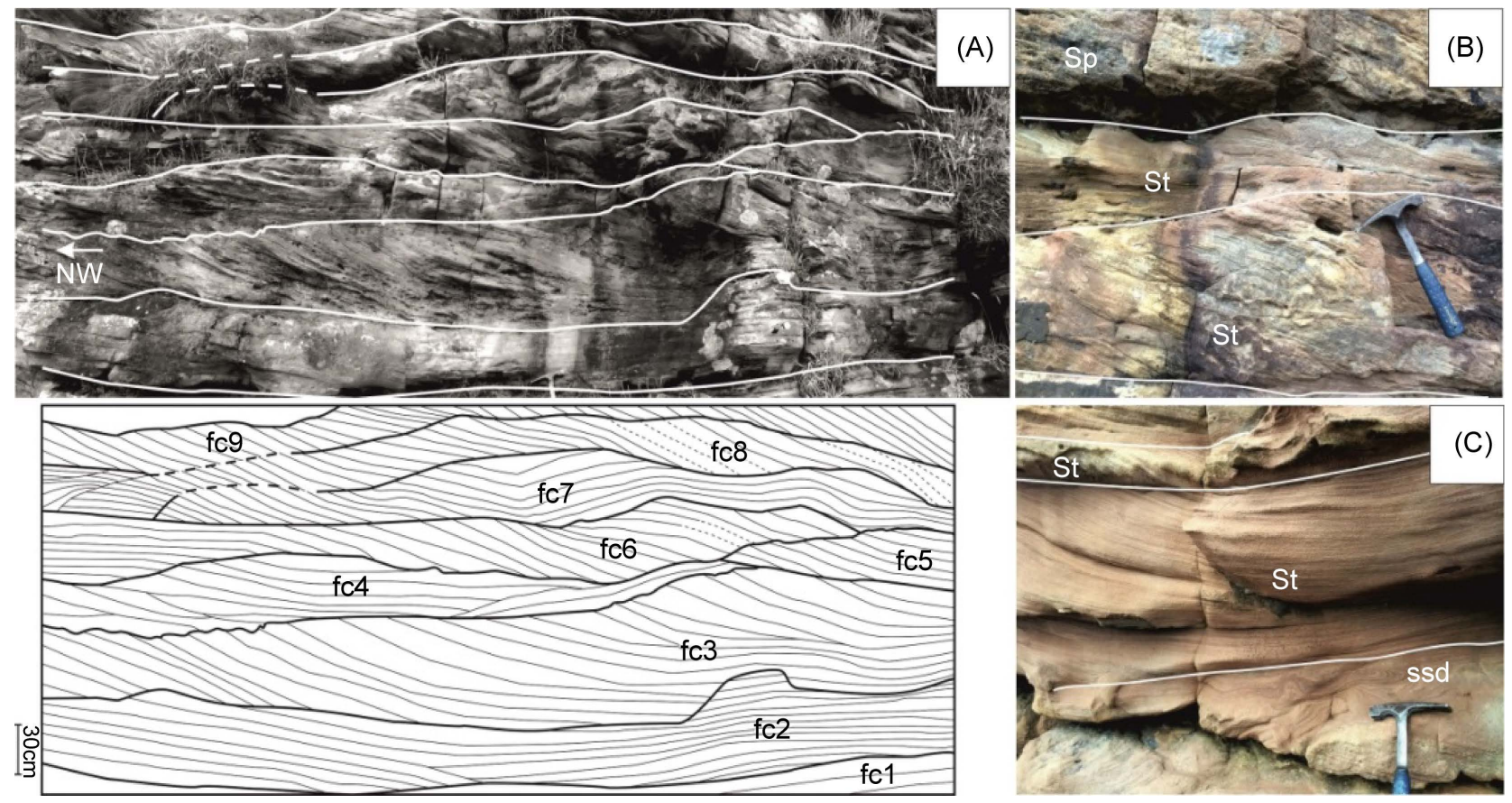

Figure 5. (A) Selected analogue outcrop profile and its simplified sketch map. (B) Stacked planar cross bedding (Sp) and trough cross bedding (St) sandstones. (C) Stacked trough cross bedding (St) sandstones and its underlying sandstone with soft sediment deformation (ssd). Note the geological hammer for scale, the handle of the hammer is about $28 \mathrm{~cm}$. 


\section{Facies Architecture Analysis}

The study on the lithofacies has revealed that the Buchan Formation in Ardmore Field is composed by sandstones mainly deposited in fluvial-braided and aeolian dune/interdune settings. By using the well logging data, geometry knowledge from analogue outcrop study and the facies modelling module in Schlumberger Petrel software, it is possible to study the facies architecture in both vertical and lateral directions. The selected profile is roughly perpendicular to the fluvial flowing (NW to SE) and palaeo wind blowing (E to W) directions [24]; and the wells are in relatively close spacing (approx. $500 \mathrm{~m}$ ) which will be helpful on increasing accuracy of lateral correlation [25]. The main parameters for Petrel facies modelling are listed in Table 3.

Table 2. Measurement of fluvial channel geometry in the outcrops.

\begin{tabular}{ccccc}
\hline \multirow{2}{*}{ Deposition unit } & Width $(\mathrm{m})$ & \multicolumn{2}{c}{ Thickness $(\mathrm{m})$} & \multirow{2}{*}{ Width/Thickness ratio } \\
\cline { 2 - 4 } & & Min & Max & \\
fc1 & 78.5 & 0.35 & 0.75 & 104.67 \\
fc2 & 63.5 & 0.25 & 0.50 & 127.00 \\
fc3 & 53.0 & 0.23 & 0.45 & 117.78 \\
fc4 & 51.0 & 0.25 & 0.45 & 113.33 \\
fc5 & 31.0 & 0.10 & 0.35 & 88.57 \\
fc6 & 41.0 & 0.15 & 0.35 & 117.14 \\
fc7 & 37.0 & 0.10 & 0.30 & 123.33 \\
fc8 & 46.0 & 0.12 & 0.50 & 92.00 \\
fc9 & 45.0 & 0.20 & 0.40 & 112.50 \\
Arithmetic average value & 49.6 & 0.2 & 0.5 & 110.7 \\
\hline
\end{tabular}

Table 3. The main parameters of Petrel facies modelling for the selected layers.

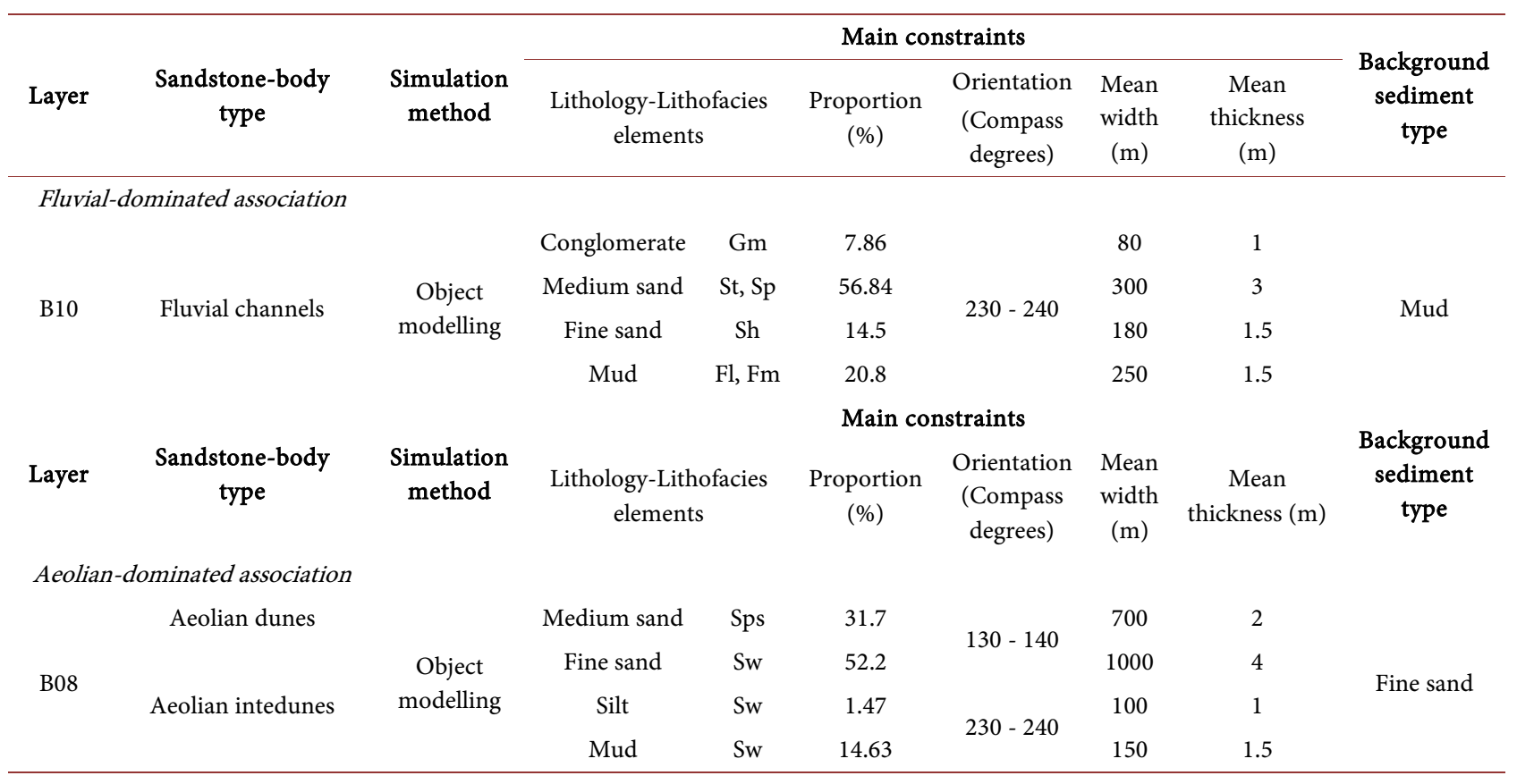




\subsection{Fluvial Association (Layer B10 as Example)}

\subsubsection{Vertical Architecture}

In the Ardmore field, layers B04, B10 and B11 are fluvial-dominated and composed by conglomerates, sandstones and fine grain sediments. Figure $6(\mathrm{~A})$ is the detailed lithology log for three wells containing Layer B10 (see Figure 1(A) for well locations). The Layer B10 in all three wells is composed by superimposed fining-upward cycles, each with 5 - 8 m thick. Each cycle generally comprises
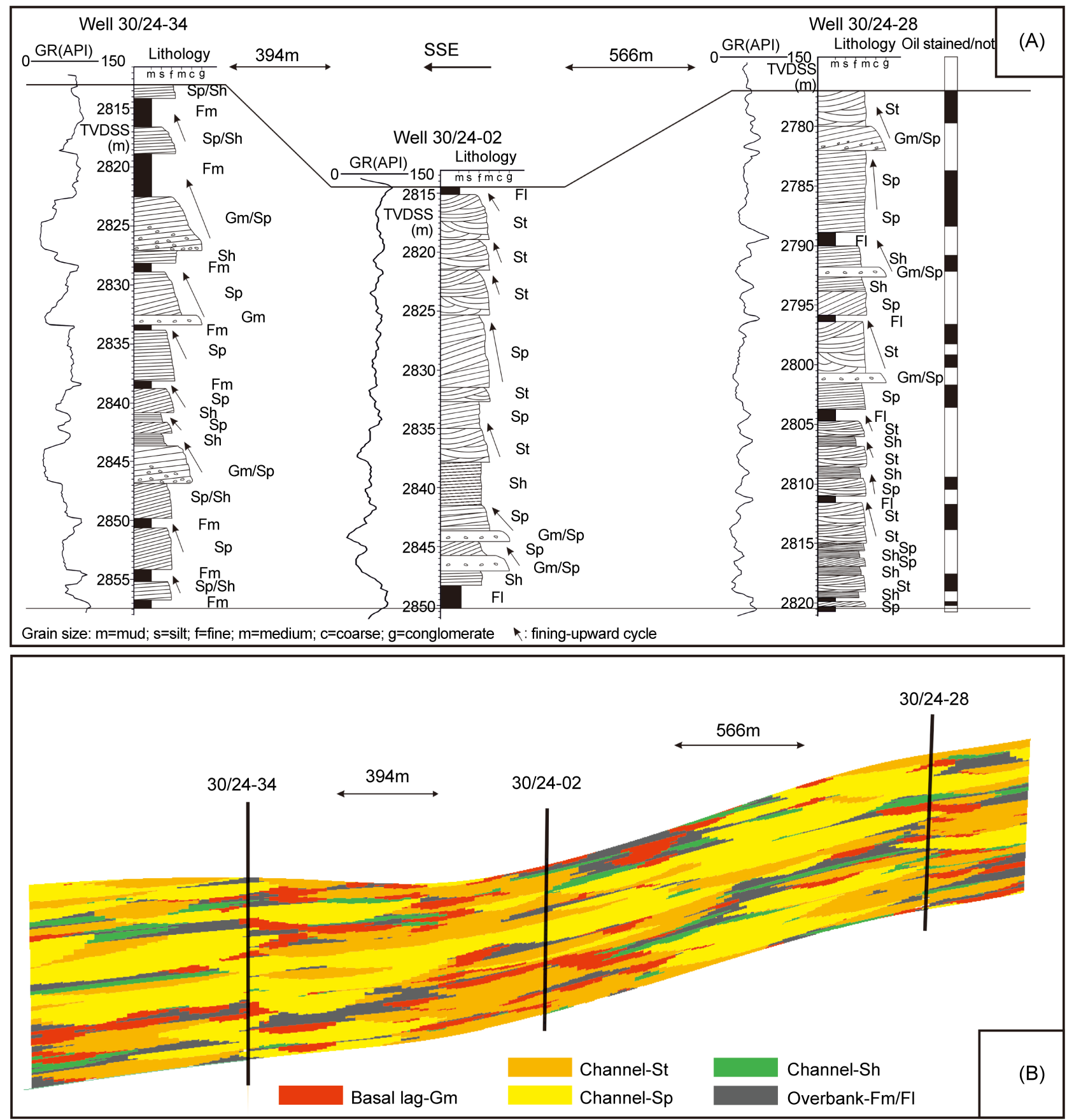

Figure 6. Well logging profile and facies modelling result of a typical fluvial association Layer B10. (A) The lithology log of selected wells, note the superimposed fining-upward cycles. (B) Petrel simulation result of the selected profile. 
minor lithofacies $\mathrm{Gm}$ at base, succeeded by predominant lithofacies $\mathrm{St}, \mathrm{Sp}$ and Sh in the middle and minor Fl/Fm on the top. The fluvial types could be classified as the combination of high-energy sand-rich and sheet-flood distal braided depositions according to the classification scheme of Miall [14]. The occurrence of fining-upward cycle indicates the deposition within channel streams [26] [27]. Therefore, the superimposed fining-upward cycles in each well represent the multi-stage developments of braided channels.

Within an individual fining-upward cycle, the lithofacies $\mathrm{Gm}$ usually forms the cycle base with thickness around $0.5-1 \mathrm{~m}$, indicates the thin basal lag deposit within a channel. The dominant lithofacies St, Sp and Sh are the most common types and form the main part of the fining-upward cycle, representing residual dunes, linguoid and transverse bars, and planar bed flows, respectively, and were produced in a low flow regime [13]. The finer grained sediments Fl and Fm indicate the decrease of flow velocity or channel abandonment [14], and separate the channel deposits and usually occur at the top of the cycle with $0.5 \mathrm{~m}$ and up to $3 \mathrm{~m}$ thick. The stained oil is mainly distributed within the lithofacies St and $\mathrm{Sp}$, indicates that braided channel sands are likely to be effective reservoir.

\subsubsection{Lateral Architecture}

The parameters for facies modelling are integrated by analogue outcrop study and depended on the actual well log correlation in Ardmore wells. In the lateral direction, the well log curves and detailed lithofacies log for three wells are not laterally correlatable, which indicate that the deposition was multiple braided channels rather than a single channel with kilometre-scale width.

The facies modelling result for Layer B10 (Figure 6(B)) shows a high gross sand ratio in the profile, the channel sand bodies are closely superimposed with adjacent ones both in vertical and lateral directions. According to the relationship between sand body connectivity and channel deposit proportion proposed by Karssenberg and Bridge [28], the high gross sand ratio $(67.18 \%$ for B04, $71.5 \%$ for B10 and $77.7 \%$ for B11) has increased the possibility that the superimposed sand bodies are almost inter-connected with each other, and only some thick muddy layers ( $>2 \mathrm{~m}$ ) could form local flow barriers.

\subsection{Aeolian Association (Layer B08 as Example)}

\subsubsection{Vertical Architecture}

In the Ardmore field, layers B07 and B08 are aeolian-dominated units and mainly composed by upper fine to medium-grained and well sorted sandstones and minor fine-grained sediments. Figure $7(\mathrm{~A})$ is the detailed lithology log for four adjacent wells containing Layer B08 (see Figure 1(A) for well locations). In the vertical direction, aeolian association shows a relatively simple architecture composed by superimposed dune and interdune depositions, there is no significant grain size variation in the vertical direction. The coarse grain sediments, such as conglomerates, are absent in the association, and the fine grain sediments occur consistently minor in four wells and increase south-eastwards. 


\subsubsection{Lateral Architecture}

The close spacing (around $500 \mathrm{~m}$ ) of development wells in Ardmore field permits the lateral correlation of aeolian units with reasonable confidence. By comparing the well log data of selected wells, the aeolian association comprises a number of laterally correlatable horizons over kilo-meter scale across the profile and generally shows a tabular geometry (Figure 7(A), Figure 7(B)). Dune sand bodies pinch out into finer grained interdune deposits, in this case the desert lake association, towards south-east, and the bounding surfaces of each horizon are commonly the overlain interdune deposits.
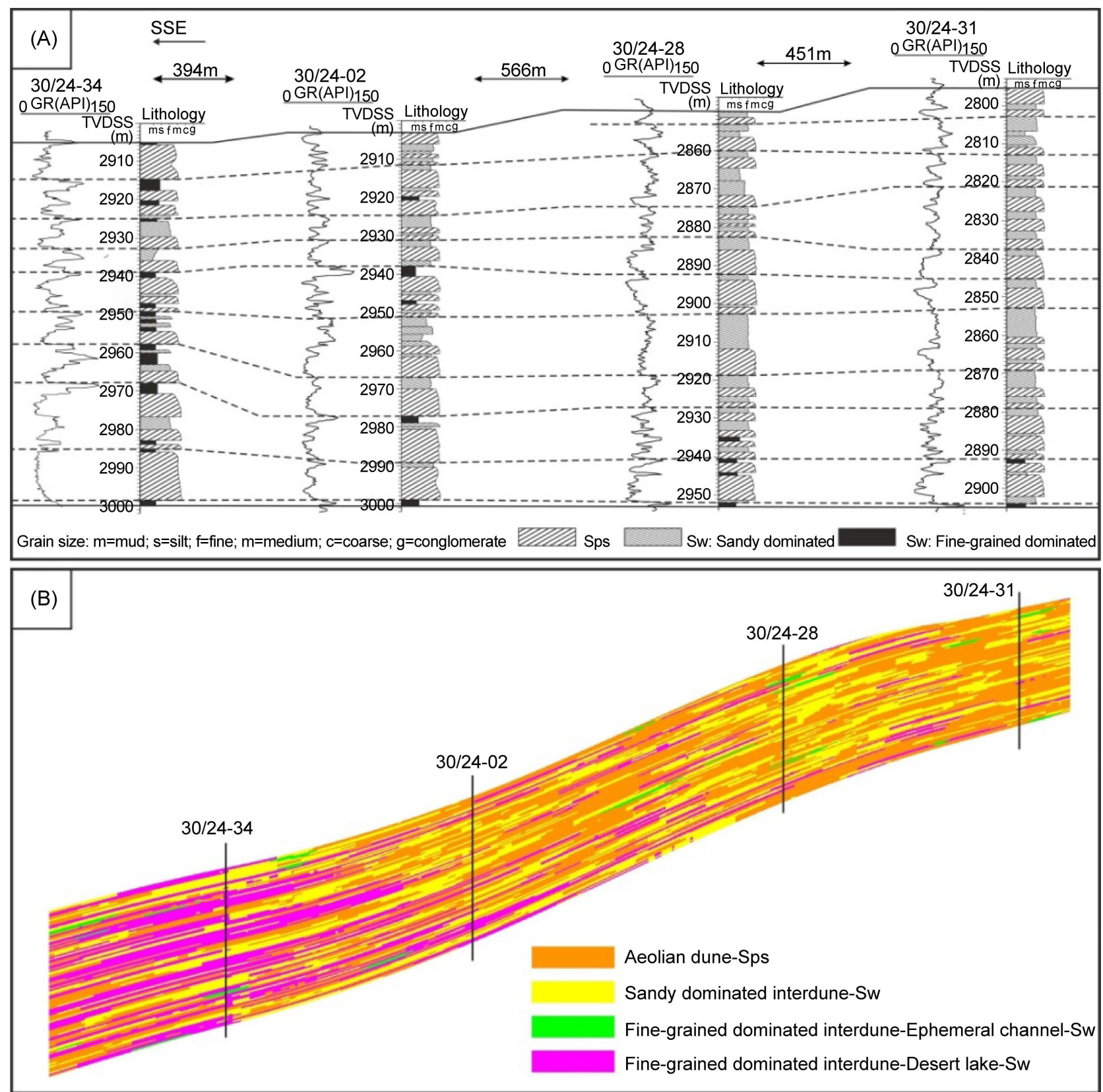

Figure 7. Well logging profile and facies modelling result of the typical aeolian association Layer B08. (A) The lithology log and lateral correlations of selected wells. (B) Petrel simulation result of the selected profile. 


\section{Discussion}

\subsection{Depositional Pattern for the Ardmore Field Area in the Late Devonian Age}

The aforementioned lithofacies and facies architecture studies have revealed that the Upper Devonian Buchan formation in the Ardmore field comprises a succession of thick terrestrial sandstones, mainly fluvial and subordinately aeolian depositions under a semi-arid to arid climate. The climatic changes, in this case the rainfall variations in the hinterland high relief area, were the main control of fluvial distributary system [29], and would occur uniformly across the basinscale area at the same time [30]. Therefore, the changes from fluvial to aeolian facies between B04 and B07/B08 (B05 and B06 are not clear), and the reverse transition from aeolian to fluvial between B07/B08 and B09-B11 may be expected to have occurred across the basin-scale area at about the same time, and presented a general progradation-retreat-progradation cycle of the alluvial fanbased braided system with aeolian deposits occurred mainly between two main progradation periods.

Therefore this study proposed a depositional pattern for the Ardmore Field area in the Late Devonian age (Figure 8). The lithofacies database is restricted to the Ardmore Field and the areas beyond that are conjectured based on previous studies on related areas.

The braided fluvial fan system was possibly sourced from high-relief uplands in Scotland Midland Valley, and flowed south-eastwards to the Central North Sea area [11] [31]. The Ardmore Field is believed locating near the margin of the braided fluvial fan system (Figure 8), as the presence of aeolian and associated desert lake sediments became established during more arid periods. Therefore, it could be generally divided into two patterns: the fluvial dominated and aeolian

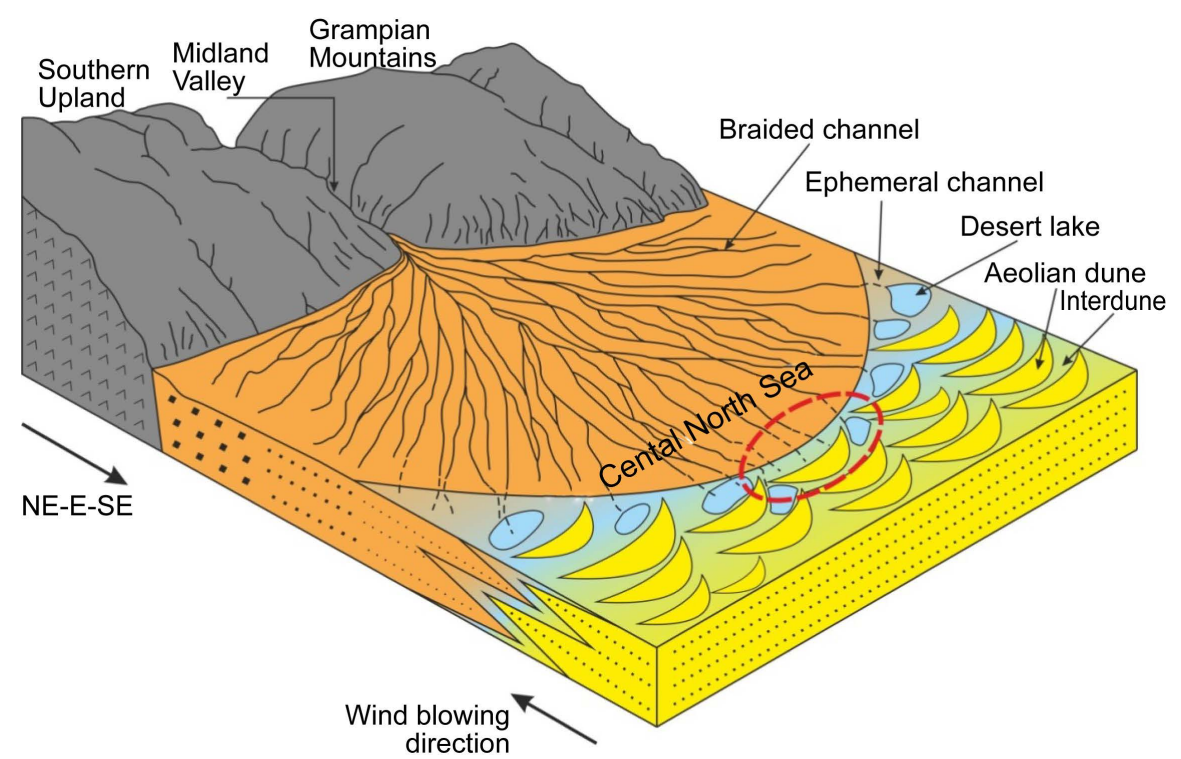

Figure 8. Schematic depositional pattern for the Ardmore field and its adjacent areas (Figure not for scale). Note the red dashed ellipse indicate the location of Ardmore field. 
dominated patterns. The bird-eye view slices of facies modelling results demonstrate more details of fluvial and aeolian dune geometry:

1) During the fluvial-dominated period, the Ardmore field was located in a braided fluvial fan with multiple conglomeratic-sandy channels and minor overbank/flood plain depositions (Figure 9(A)). The braided fluvial sedimentation was featured as poorly confined channels with rapid and frequent lateral migrations, the cross section of a single channel, according to the analogue outcrops, shows a sheet-like sand body with high width-thickness ratio. This could be explained by the weak riverbank stability due to the lack of deeply rooted vegetation in the Devonian age [32] [33] and overall arid climate which enabled the frequent lateral migration of channel deposits.

2) During aeolian-dominated period, the dune and interdune deposits were predominated and the wind direction was suggested as blowing from east to west [24]. Clearly not all the interdune deposits were aeolian origin, but also the modification by the loading occasional fluvial deposits. There were no conglomeratic-sandy channel deposits during this period, and only some distal fluvial deposits (e.g. sheet flood, floodplain, etc.) could affect the study area (Figure 9(B)). The fluvial-origin fine grained sediments were deposited in the topographically lower area, in this case, the interdune facies. During this period, occasional desert lakes could exist when the water table was high. The dune and
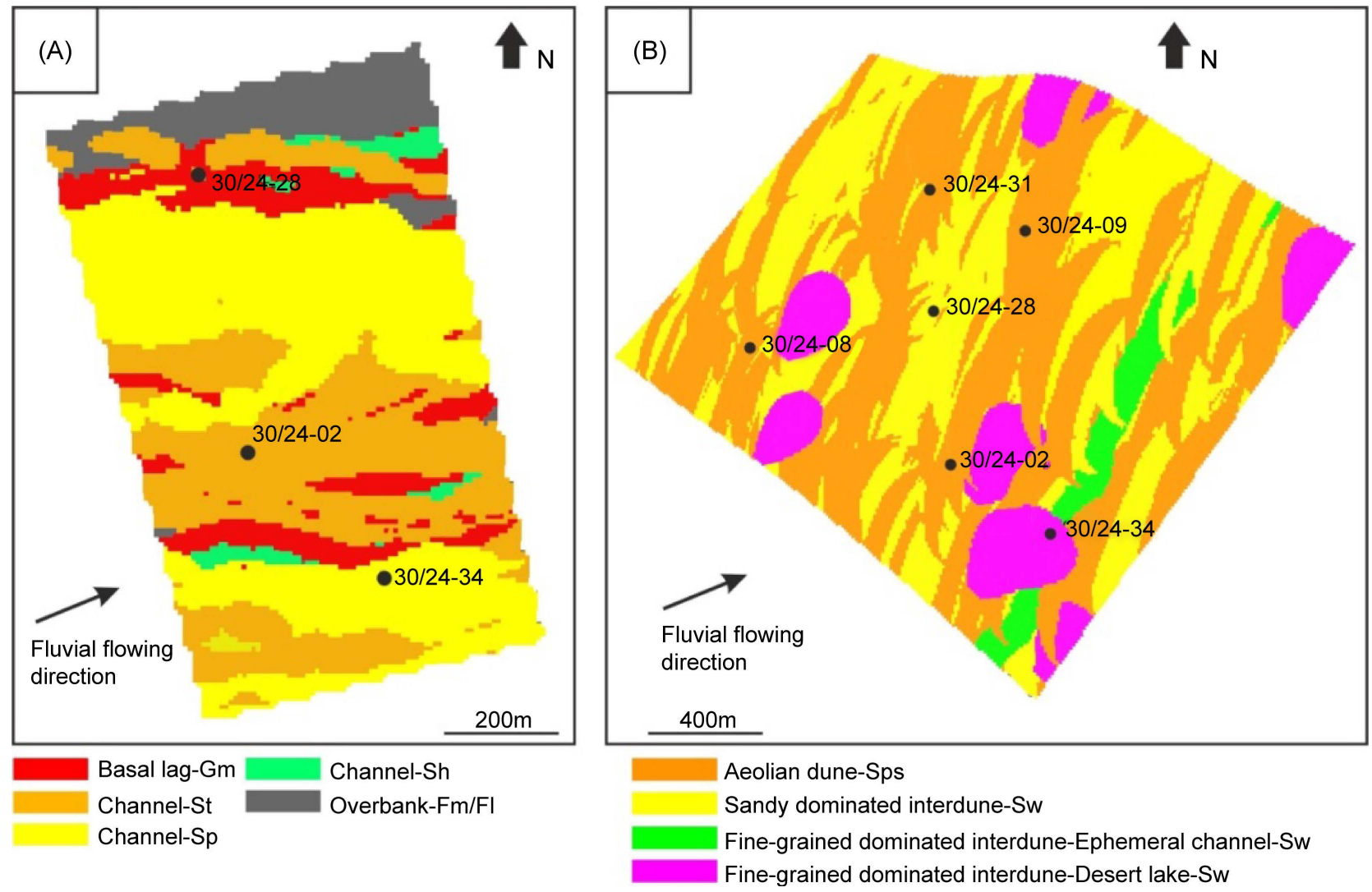

Figure 9. Bird-eye view slices generated by Petrel facies modelling for: (A) Layer B10, typical fluvial-dominated unit. (B) Layer B08, typical aeolian-dominated unit. 
interdune facies are laterally extensive which suggests the stable development of aeolian deposition, either as the consequences of major channel switching and/ or the regionally significant hiatus of fluvial activity.

\subsection{Significance of Identifying Aeolian Deposits}

Aeolian facies is commonly featured as widespread occurrence and good reservoir properties, which usually make aeolian sandstones attractive exploration targets [34]. In the Ardmore field, the reservoir quality of volumetrically major fluvial sandstones was significantly suffered by cementation of extensive quartz overgrowths and authigenic dolomites [1], porosity ranges from $6 \%$ to $24 \%$, but permeability never exceeded $300 \mathrm{mD}$ (Figure 10(A)). Conversely, aeolian deposits possess volumetrically minor component but both dune and interdune facies show good reservoir quality (Figure 10(B)).

Therefore, it is important to identify the aeolian association as early as possible during exploration or development. Due to the presence of conglomerates and highly cemented sandstones, the well log responses of fluvial sandstones are commonly featured as medium-low gamma ray value (50 - $80 \mathrm{API})$, low sonic transit times $(<75 \mu \mathrm{s} / \mathrm{ft})$ and medium-high density $\left(>2.5 \mathrm{~g} / \mathrm{cm}^{3}\right)$, and each conglomerate-sandstone group is separated by an overbank-associated muddy layer whose gamma ray value is greater than 100 API (Figure 11(A)). However, the aeolian deposits are sandy-dominated with high compositional and textual maturity, high porosity, low cementation and absence of conglomerates and muddy contents, therefore, these features can be manifested on well log curves by low gamma ray value (consistently less than $75 \mathrm{API}$ ), high sonic transit times (consistently greater than $80 \mu \mathrm{s} / \mathrm{ft}$ ) and low density $\left(<2.5 \mathrm{~g} / \mathrm{cm}^{3}\right)$. These featured well
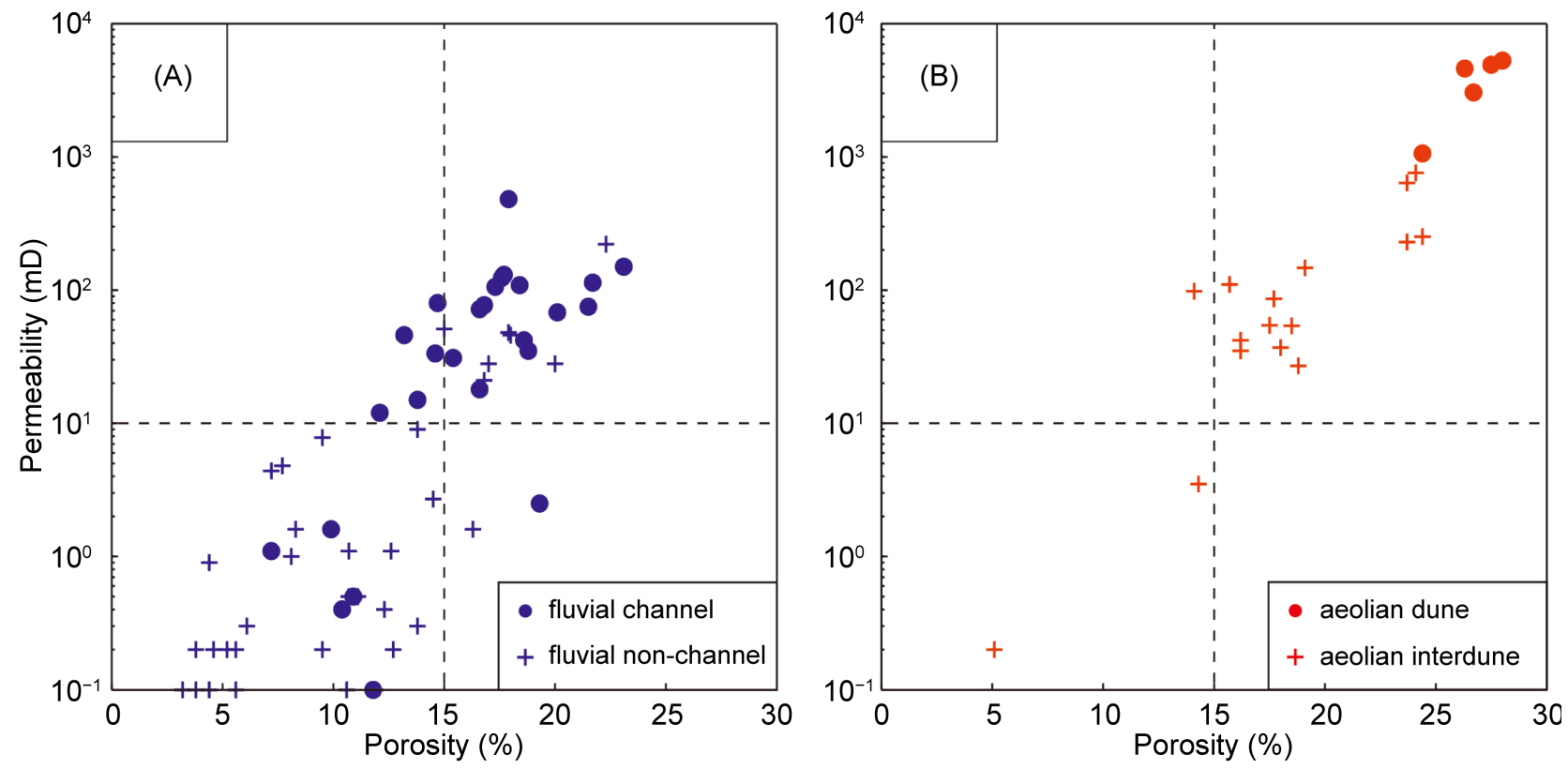

Figure 10. The scattered porosity and permeability maps for: (A) Fluvial-associated sandstones. (B) Aeolian-associated sandstones. Note porosity $=15 \%$ and permeability $=10 \mathrm{mD}$ are set as the lower limits of effective reservoir. 

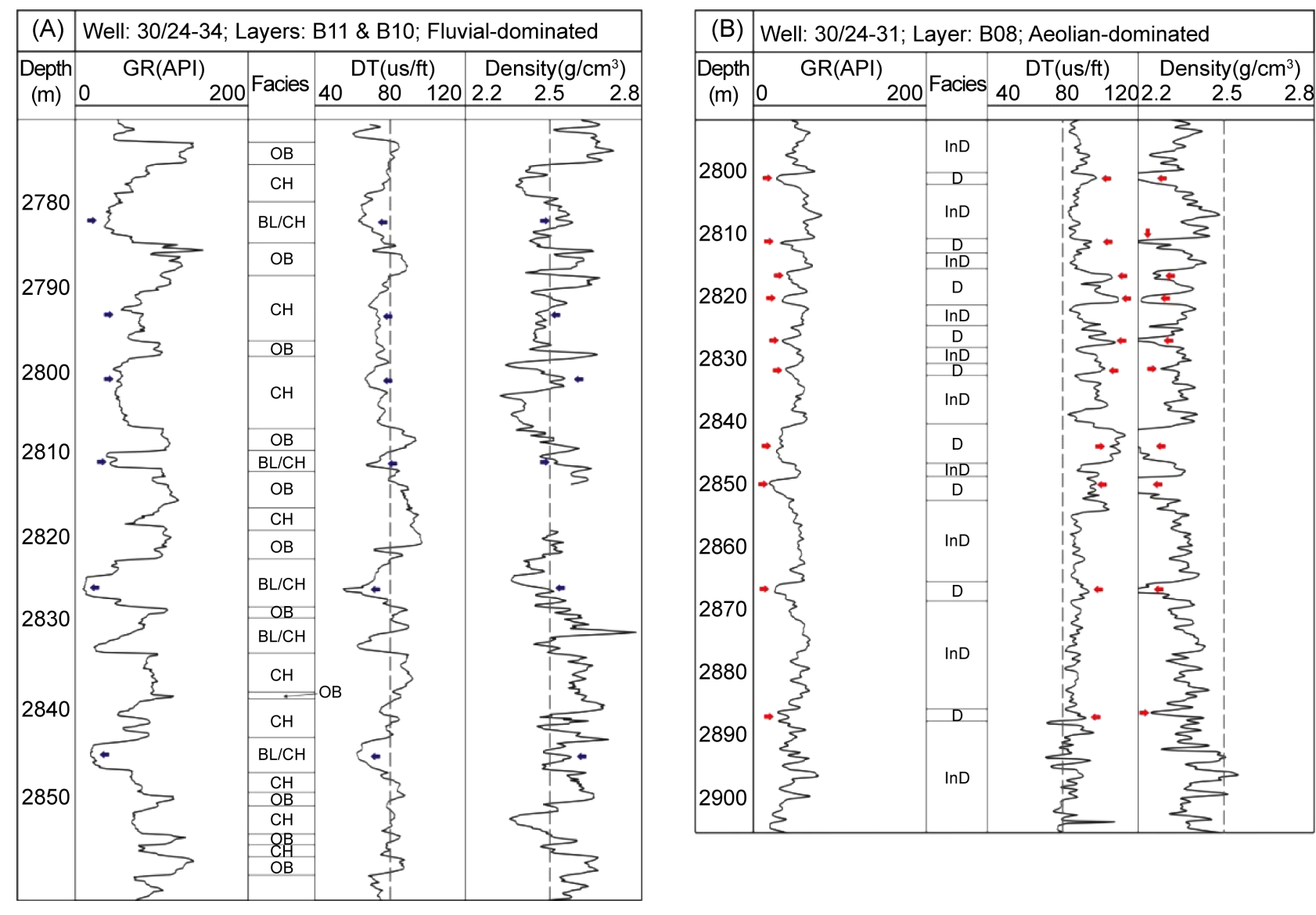

Figure 11. Different well log responses for (A) Fluvial-dominate intervals, note in blue arrows indicate the features of low gamma ray, low sonic log and high density in fluvial channel sandstones, $\mathrm{BL}=$ basal lag, $\mathrm{CH}=$ channel, $\mathrm{OB}=$ overbank. (B) Aeolian-dominated interval, note the red arrows indicate the features of low gamma ray, high sonic log and low density in aeolian dune sandstones, $\mathrm{D}=$ dune, $\mathrm{InD}=$ interdune.

log responses, combined with uniform dipmeter patterns (not shown in the Figure), make it possible to tentatively identify aeolian facies in uncored wells (Figure 11(B)).

\subsection{Implications on Devonian-Associated Reservoir Explorations}

Devonian strata in the North Sea have been perceived little hydrocarbon potential for a long time [35], but several fields in both UK and Norwegian North Sea have confirmed the industrial oil productions from Devonian-associated reservoirs in recent decades [10] [36] [37] [38].

In this study, we confirm that the Buchan formation in Ardmore Field is composed not only by fluvial deposits but also the presence of aeolian components. Aeolian components possess volumetrically minor percentage (approx. $30 \%$ ) but show the best reservoir quality among the whole Buchan formation: in fluvial sandstones, the extensive quartz and dolomite cementation reduces permeability by $1-2$ orders of magnitude; however, quartz overgrowth is absent in aeolian sandstones. Given the same tectonic setting and burial process, these contrasting differences have two implications: 1) the relationship of porosity and 
permeability is different in fluvial and aeolian sandstones; and 2) the fluvial and aeolian sandstones have undergone different diagenesis processes. These make the sandwiched aeolian sandstones can still keep good porosity/permeability even the surrounding fluvial sandstones were significantly cemented.

In the Ardmore field, aeolian sandstones are thin, laterally extensive, poorly cemented and permeable, and interbedded with thick, cemented and low-permeability fluvial sandstones. Since the North Sea area had similar depositional setting in the Late Devonian age, therefore, careful facies identification is important for determining the presence of aeolian sandstones. This study has improved the knowledge of depositional setting in the study area and provided several tentative criteria for recognizing aeolian sandstones for the uncored wells; the results can have broad applications on future exploration in Devonian targets of the North Sea or other places with similar provenance.

\section{Conclusions}

A renewed attempt on facies identification and modelling has been made by using lithofacies, analogue outcrops, well logging data and software simulation. This study has announced the presence of aeolian sandstones within the fluvialdominated Buchan formation in the Ardmore field, which has not been clearly identified in the previous time.

Fluvial-associated sandstones are volumetrically major facies type (approx. $70 \%)$ and typical braided origin. They are composed by superimposed finingupward cycles, and each cycle represents a deposition of channel bar or channel fills; none of channel deposits can be correlated among the inter-well distance, but the high channel deposition proportion indicate that the channel sandstones are likely to be interconnected with each other.

Aeolian-associated facies form a volumetrically minor (approx. 30\%) but important reservoir in the studied field. They comprise superimposed dune and interdune sandstones and are laterally correlatable over kilometre scale. Both dune and interdune sandstones have good reservoir quality as a consequence of good sorting, roundness, absence of muddy and conglomeratic contents, and low cementation. These features allow them to be tentatively identified, especially for those uncored wells, by using the combination of well log responses: low gamma ray, high sonic transit time and low density.

Understandings on the scheme of this fluvial-aeolian facies system demonstrate the possibility of effective reservoir potential in Devonian strata, sandstones deposited in different facies would undergo different diagenesis, in this case, the sandwiched aeolian sandstones could still hold good reservoir property even the surrounding fluvial sandstones were highly cemented. This should have an important impact on reservoir identification, appraisal and discovery.

\section{Acknowledgements}

The authors thank Enquest PLC for supporting this research through access to 
core, seismic sections and other data and financial support for field work and petrographic analyses; Dr Bernard Besley for providing data and helpful discussions; Mr Russel Ball (San Leon Energy PLC) for providing helpful skills on facies modelling in Petrel; BGS (British Geological Survey) for its assistance in facilitating the examination of Devonian cores.

\section{References}

[1] Bifani, R. and Smith, C. (1985) The Argyll Field after a Decade of Production in Offshore Europe. Society of Petroleum Engineers. https://doi.org/10.2118/13987-MS

[2] Robson, D. (1991) The Argyll, Duncan and Innes Fields, Block 30/24 and 30/25a, UK North Sea. Geological Society, London, Memoirs, 14, 219-226. https://doi.org/10.1144/GSL.MEM.1991.014.01.27

[3] Gluyas, J.G. and Hichens, H.M. (2003) United Kingdom Oil and Gas Fields: Commemorative Millennium Volume.

[4] Howell, J. and Mountney, N. (1997) Climatic Cyclicity and Accommodation Space in Arid to Semi-Arid Depositional Systems: An Example from the Rotliegend Group of the UK Southern North Sea. Geological Society, London, Special Publications, 123, 63-86. https://doi.org/10.1144/GSL.SP.1997.123.01.05

[5] Sweet, M. (1999) Interaction between Aeolian, Fluvial and Playa Environments in the Permian Upper Rotliegend Group, UK Southern North Sea. Sedimentology, 46, 171-188. https://doi.org/10.1046/j.1365-3091.1999.00211.x

[6] George, G.T. and Berry, J.K. (1993) A New Lithostratigraphy and Depositional Model for the Upper Rotliegend of the UK Sector of the Southern North Sea. Geological Society, London, Special Publications, 73, 291-319. https://doi.org/10.1144/GSL.SP.1993.073.01.18

[7] Nagtegal, P. (1979) Relationship of Facies and Reservoir Quality in Rotliegendes Desert Sandstones, Southern North Sea Region. Journal of Petroleum Geology, 2, 145-158. https://doi.org/10.1111/j.1747-5457.1979.tb00699.x

[8] Purvis, K. (1992) Lower Permian Rotliegend Sandstones, Southern North Sea: A Case Study of Sandstone Diagenesis in Evaporite-Associated Sequences. Sedimentary Geology, 77, 155-171.

[9] Glennie, K. and Provan, D. (1990) Lower Permian Rotliegend Reservoir of the Southern North Sea Gas Province. Geological Society, London, Special Publications, 50, 399-416. https://doi.org/10.1144/GSL.SP.1990.050.01.25

[10] Gluyas, J., et al. (2005) Ardmore Field: Rebirth of the First Offshore Oil Field, UKCS. Geological Society, London, Petroleum Geology Conference Series, Geological Society of London.

[11] Graham, C., et al. (2003) The Millennium Atlas: Petroleum Geology of the Central and Northern North Sea. Geological Society of London.

[12] Trewin, N.H. and Bramwell, M.G. (1991) The Auk Field, Block 30/16, UK North Sea. Geological Society, London, Memoirs, 14, 227-236. https://doi.org/10.1144/GSL.MEM.1991.014.01.28

[13] Miall, A.D. (1977) Lithofacies Types and Vertical Profile Models in Braided River Deposits: A Summary.

[14] Miall, A. (2013) The Geology of Fluvial Deposits: Sedimentary Facies, Basin Analysis, and Petroleum Geology. Springer, Berlin. 
[15] McKee, E., Crosby, E.T. and Berryhill, H. (1967) Flood Deposits, Bijou Creek, Colorado, June 1965. Journal of Sedimentary Petrology, 37, 829-851. https://doi.org/10.1306/74D717B2-2B21-11D7-8648000102C1865D

[16] Hunter, R.E. (1977) Basic Types of Stratification in Small Eolian Dunes. Sedimentology, 24, 361-387. https://doi.org/10.1111/j.1365-3091.1977.tb00128.x

[17] Kocurek, G. and Dott, R.H. (1981) Distinctions and Uses of Stratification Types in the Interpretation of Eolian Sand. Journal of Sedimentary Petrology, 51, 579-595.

[18] Fryberger, S.G. and Schenk, C.J. (1988) Pin Stripe Lamination: A Distinctive Feature of Modern and Ancient Eolian Sediments. Sedimentary Geology, 55, 1-15.

[19] Langford, R.P. (1989) Fluvial-Aeolian Interactions: Part I, Modern Systems. Sedimentology, 36, 1023-1035. https://doi.org/10.1111/j.1365-3091.1989.tb01540.x

[20] Ziegler, P.A. (1990) Geological Atlas of Western and Central Europe. Geological Society of London.

[21] Glennie, K. (2009) Petroleum Geology of the North Sea: Basic Concepts and Recent Advances. John Wiley \& Sons, Hoboken.

[22] Trewin, N.H. and Hurst, A. (2009) Excursion Guide to the Geology of East Sutherland and Caithness. Dunedin Academic Press Ltd.

[23] Trewin, N. (1989) The Petroleum Potential of the Old Red Sandstone of Northern Scotland. Scottish Journal of Geology, 25, 201-225.

https://doi.org/10.1144/sjg25020201

[24] Hall, I. and Chisholm, J. (1987) Aeolian Sediments in the Late Devonian of the Scottish Midland Valley. Scottish Journal of Geology, 23, 203-208. https://doi.org/10.1144/sjg23020203

[25] Miall, A.D. (1988) Reservoir Heterogeneities in Fluvial Sandstones: Lessons from Outcrop Studies. AAPG Bulletin, 72, 682-697.

[26] Bongiolo, D.E. and Scherer, C.M. (2010) Facies Architecture and Heterogeneity of the Fluvial-Aeolian Reservoirs of the Sergi Formation (Upper Jurassic), Recôncavo Basin, NE Brazil. Marine and Petroleum Geology, 27, 1885-1897.

[27] Bridge, J.S. and Lunt, I.A. (2006) Depositional Models of Braided Rivers. Braided Rivers, Processes, Deposits, Ecology and Management. International Association of Sedimentologists, 36, 11-50.

[28] Karssenberg, D. and Bridge, J.S. (2008) A Three-Dimensional Numerical Model of Sediment Transport, Erosion and Deposition within a Network of Channel Belts, Floodplain and Hill Slope: Extrinsic and Intrinsic Controls on Floodplain Dynamics and Alluvial Architecture. Sedimentology, 55, 1717-1745. https://doi.org/10.1111/j.1365-3091.2008.00965.x

[29] Nichols, G. and Fisher, J. (2007) Processes, Facies and Architecture of Fluvial Distributary System Deposits. Sedimentary Geology, 195, 75-90.

[30] Nichols, G. (2005) Sedimentary Evolution of the Lower Clair Group, Devonian, West of Shetland: Climate and Sediment Supply Controls on Fluvial, Aeolian and Lacustrine Deposition. Geological Society, London, Petroleum Geology Conference Series, Geological Society of London.

[31] Bluck, B. (2000) Old Red Sandstone Basins and Alluvial Systems of Midland Scotland. Geological Society, London, Special Publications, 180, 417-437. https://doi.org/10.1144/GSL.SP.2000.180.01.22

[32] Davies, N.S. and Gibling, M.R. (2010) Paleozoic Vegetation and the Siluro-Devonian Rise of Fluvial Lateral Accretion Sets. Geology, 38, 51-54.

https://doi.org/10.1130/G30443.1 
[33] Gibling, M., et al. (2014) Palaeozoic Co-Evolution of Rivers and Vegetation: A Synthesis of Current Knowledge. Proceedings of the Geologists Association, 125, 524533.

[34] Ahlbrandt, T.S. and Fryberger, S.G. (1982) Introduction to Eolian Deposits.

[35] Downie, R. (2009) Devonian. Petroleum Geology of the North Sea: Basic Concepts and Recent Advances. 4th Edition, 85-103.

[36] Edwards, C. (1991) The Buchan Field, Blocks 20/5a and 21/1a, UK North Sea. Geological Society, London, Memoirs, 14, 253-259. https://doi.org/10.1144/GSL.MEM.1991.014.01.31

[37] Gambaro, M. and Currie, M. (2003) The Balmoral, Glamis and Stirling Fields, Block 16/21, UK Central North Sea. Geological Society, London, Memoirs, 20, 395-413. https://doi.org/10.1144/GSL.MEM.2003.020.01.33

[38] Knight, I., et al. (1993) The Embla Field. Geological Society, London, Petroleum Geology Conference Series, Geological Society of London.

Submit or recommend next manuscript to SCIRP and we will provide best service for you:

Accepting pre-submission inquiries through Email, Facebook, LinkedIn, Twitter, etc. A wide selection of journals (inclusive of 9 subjects, more than 200 journals)

Providing 24-hour high-quality service

User-friendly online submission system

Fair and swift peer-review system

Efficient typesetting and proofreading procedure

Display of the result of downloads and visits, as well as the number of cited articles

Maximum dissemination of your research work

Submit your manuscript at: http://papersubmission.scirp.org/

Or contactijg@scirp.org 